\title{
K-systems analysis for determining the factors influencing benthic microfloral productivity in a Louisiana estuary, USA
}

\author{
Gary P. Shaffer \\ Coastal Ecology Institute and Department of Experimental Statistics, Louisiana State University, Baton Rouge, \\ Louisiana 70803-7503, USA
}

\begin{abstract}
About 3000 sediment cores from Barataria Estuary, Louisiana, USA, were incubated between $26 \mathrm{Jul}$ and $25 \mathrm{Aug}$ 1983. For the month, benthic microfloral production measured at a subtidal site consisting of muddy sand was almost twice that measured at a sandy intertidal site $\left(27 \mathrm{~g} \mathrm{C} \mathrm{m}^{-2}\right.$ vs $14 \mathrm{~g} \mathrm{C} \mathrm{m}^{-2}$ ). However, maximum productivity rates $\left(230 \mathrm{mg} \mathrm{C} \mathrm{m}^{-2} \mathrm{~h}^{-1}\right.$ ) were greatest at the sandy site; these rates occurred under periods of subaerial exposure which were limited to late afternoons on $11 \mathrm{~d}$ of the study, yet accounted for $43 \%$ of the total monthly production at the sand site. Other variables monitored were chlorophyll $a$, light intensity, water temperature, salinity, benthic community respiration, productivity of the water column, biological activity (muddy sand site), wave height (sand site), meteorological tides (wind-induced water levels), tide height, and initial dissolved oxygen. Multichannel information analysis indicated that the information accounted for in productivity by these variables peaked at slightly less than 7 and $3 \mathrm{~d}$ periods for the sand site and weak peaks occurred at about 10 and $3 \mathrm{~d}$ periods for the muddy sand site. K-systems analysis indicated that the environmental variables acted in combination to influence productivity, and that the combinations changed through time. Physical processes (meteorologic, astronomic, and anthropogenic) largely controlled productivity at the sand site. Productivity at the muddy sand site was influenced by a combination of physical and biological activities.
\end{abstract}

\section{INTRODUCTION}

Little is known about the importance of the benthic microflora in US Gulf coast estuarine ecosystems, despite the vast expanse of subtidal and intertidal sand and mud flats in the region. The processes governing benthic microfloral productivity are also poorly understood. Generally, studies designed to determine the importance of benthic microfloral production measure productivity one or more times each month, and convert the hourly rates to an annual estimate (Pomeroy 1959, Pamatmat 1968, Steele \& Baird 1968, Leach 1970 , Cadée \& Hegeman 1974, 1977, Gallagher \& Daiber 1974, van Raalte et al. 1976, Joint 1978, Baillie \& Welsh 1980, Zedler 1980, Rutgers van der Loeff et al. 1981, van Es 1982, Colijn \& de Jonge 1984, Rizzo \& Wetzel 1985). It was demonstrated by Shaffer \& Onuf (1985) that the errors due to inappropriate assumptions in converting hourly productivity to annual production combined with the errors due to inappropriate sampling in space and time are equal to the full range of variation in existing annual estimates for different regions of the world.

In several of the annual studies (e.g. van Es 1982, Shaffer \& Onuf 1983, Colijn \& de Jonge 1984, Rizzo \& Wetzel 1985) attempts have been made to account for the variation in productivity by simultaneously measuring other variables and relating these to productivity via standard statistical procedures. Generally, these studies show that significant correlations exist between productivity and some of the independent variables, but that a large portion of the variability in productivity remains unaccounted for. As demonstrated in Shaffer \& Cahoon (1987), the 2 primary reasons for this lack of resolution are: (1) productivity and the factors which control productivity change rapidly over time and previous sampling designs do not reflect these scales, and (2) standard statistical procedures are largely inappropriate because of the dynamic relations between productivity and the individual environmental variables. Unlike standard statistical techniques, K-systems analysis (also called entropy data analysis) analyzes 
data in pieces (states and substates; Jones 1985a, b, c, 1986) and thereby can capture dynamic relationships among variables. By employing an intensive monthlong sampling scheme (10 to $12 \mathrm{~h}$ per day for 31 consecutive days) and subjecting the data to $\mathrm{K}$-systems analysis, an attempt was made in Barataria Estuary. Louisiana, to determine the potential importance of benthic microfloral productivity, and to determine what factors control that productivity.

\section{MATERIALS AND METHODS}

Study area. The study was conducted on the southwestern terminus of the barrier island Grand Terre, located in the vicinity of $29^{\circ} 16^{\prime} \mathrm{N}$ latitude and $89^{\circ} 57^{\prime} \mathrm{W}$ longitude (approximately $65 \mathrm{~km}$ northwest of the present Mississippi River delta and $80 \mathrm{~km}$ south of New Orleans). Grand Terre is one of several barrier islands bordering Barataria Bay (Fig. 1), a shallow water estu- ary (mean depths ranging from 0.3 to $1.7 \mathrm{~m}$ ). The estuary is well-mixed due to these limited water depths and the daily influx of tidal water and fresh water (Adams et al. 1976). The salinity of the bay averages $22 \%$ and ranges from 12 to $27 \%$. The environment is microtidal with a diumal tide of $0.37 \mathrm{~m}$ mean range, a tropic tide range of $0.61 \mathrm{~m}$, and a low wave energy of $0.45 \mathrm{~m}$ mean height (Byrne et al. 1976). The dominant wind and wave direction is from the south and southeast. Although daily wave conditions are generally mild, summer storms and winter cold fronts may result in wave heights of $2.5 \mathrm{~m}$ or more (Adams et al. 1976). The coarsest sediments are fine grain sands $(125 \mu \mathrm{m})$ located along the beaches and shallow water areas of the beaches adjacent to the inlet (Krumbein \& Aberdeen 1937). Fine sand is generally the coarsest terrigenous sediment on the whole south Louisiana coast, reflecting the fine grain character of the recent Mississippi River fluvial system (Shamban 1985).

Productivity measurements. Gross productivity of

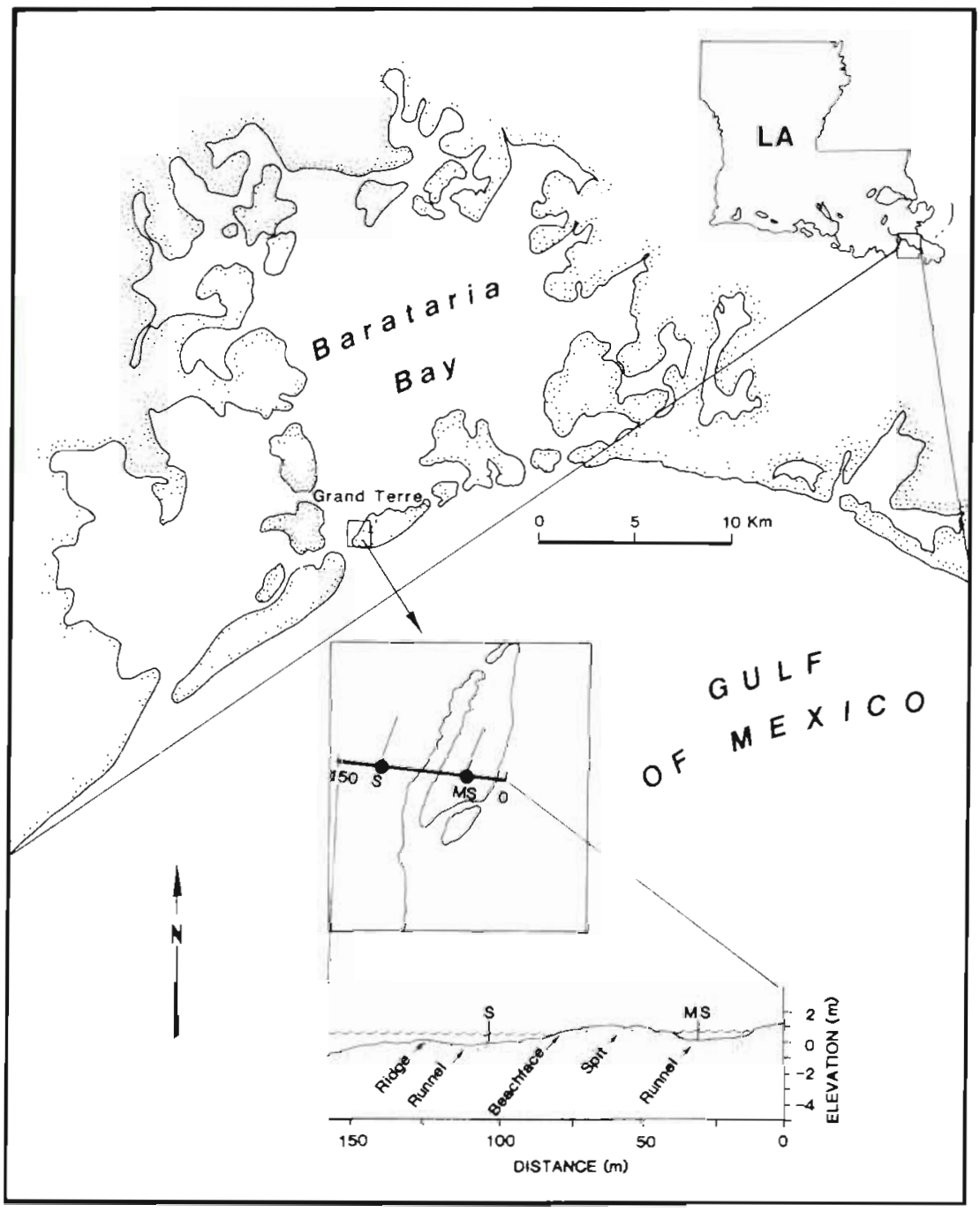

Fig. 1 Barataria Estuary, its location in Louisiana, USA, and locations of the sample sites (S: sand MS: muddy sand) 
the benthic microflora and respiration of the benthic community inhabiting the upper $0.5 \mathrm{~cm}$ of the sediment were determined by incubating intact sediment cores in stirred 51 light-dark chambers at the sample site, and measuring changes in dissolved oxygen with a YSI oxygen probe calibrated daily using the Winkler technique (Strickland \& Parsons 1972). In addition, Winkler titrations were performed on 3 to 6 samples from the field, at least every second day, and without exception the oxygen probe proved accurate. Incubation periods were between 0.45 and $1.25 \mathrm{~h}$. The measurements were conducted in situ between 1000 and $1430 \mathrm{~h}$. Incubations were carried out every day from 26 Jul to 25 Aug 1983. In addition, a second set of incubations were made during times (late afternoon on $11 \mathrm{~d}$ ) of low tide and subaerial exposure at the sand site.

The incubation chambers (1 light, 1 dark) each contained 20 intact sediment cores $13.4 \mathrm{~cm}$ diameter, $0.5 \mathrm{~cm}$ deep). The coring procedure caused little or no disturbance of the visible film of microflora on the core surface. To obtain the 40 cores for the 2 chambers, duplicate samples were taken (about 3 to $5 \mathrm{~cm}$ apart) at each of 20 sample sites located at predetermined distances along a $24 \mathrm{~m}$ long transect $(1 \mathrm{~m}$ apart, as suggested by Shaffer \& Cahoon 1987).

Each day a $0.81 \mathrm{~m}^{2}$ quadrat, divided into 36 cells, was set at each of the 20 sample sites. One of the 36 cells was randomly preselected for each day: no cell was sampled on more than one day. This sampling design assured that all samples at each of the 20 sites were discrete distances apart, yet eliminated the possibility that any sample taken late in the study had been disturbed by removal of samples from the same site earlier (Shaffer \& Onuf 1985).

These productivity measurements based on 40 cores were made at an intertidal station consisting of wellsorted fine sands (Folk 1968) and a subtidal site consisting of fine muddy sands covered by a thin veneer ( 1 to $2 \mathrm{~mm}$ ) of mud, held together by a diatom/blue-green algal matrix. In addition, water column productivity was measured in $300 \mathrm{ml}$ light-dark bottles (Strickland $\&$ Parsons 1972) incubated for about $2 \mathrm{~h}$ at the sample sites (Shaffer \& Sullivan 1988). The 2 sites (Fig. 1) are separated by a sandspit created by one of the ridge and runnel systems (which proved to be an important feature in influencing productivity and standing crop of the benthic microflora) common all along the beach. These systems are in a constant state of flux: the ridges migrate shoreward, eventually welding to the beach face and creating a new berm with the runnel becoming an intertidal or subtidal pool (e.g. the muddy sand site). Continued onshore movement of the ridge, combined with wave uprush, begins to fill the runnel with sand. As the runnel completely welds to the beach, a new ridge and runnel system begins to form in the surf zone just offshore. Storms and lunar tidal cycles (affecting water levels), in addition to wave processes, greatly influence the behavior of these systems.

After the productivity measurements were made, the 20 cores from each chamber were pooled for a cumulative measurement of the concentration of chlorophyll a in the sediments. Chemical extractions were performed according to the method of Strickland \& Parsons (1972). The concentration was determined by the formulae of Lorenzen (1967), following the suggestions of Reimann (1978) in correcting for pheopigments. Photosynthetically active radiation was measured during all incubations in $\mu \mathrm{E} \mathrm{m} \mathrm{m}^{-2} \mathrm{~s}^{-1}$ with a LI-COR 185-B quantum meter. The sensor was placed through a hole in the bottom of a light chamber, thus measuring the insolation reaching the sediment cores through the water and the chamber lid. In addition, light was monitored continuously (on a laboratory roof-top approximately $0.5 \mathrm{~km}$ from the sample sites) with an Eppley 8-48 pyronometer. To estimate daily production, the formula for 'Actual' production in Shaffer \& Onuf (1985, p. 227) was used. This required application of a turbidity factor to the roof-top measurements. A separate turbidity factor was obtained each day for each site as the ratio of insolation reaching the cores to the insolation measured subaerially. Other variables measured were water temperature next to the sediment cores, initial dissolved oxygen, benthic community respiration, salinity, mean tidal range, wave and tide height (measured water level) during sampling, biological disturbance (qualitative [high, low] observations of faunal activity during the 10 to $12 \mathrm{~h}$ in the field each day), and meteorological tides (measured water level minus predicted hourly astronomical tide level) during the $24 \mathrm{~h}$ period previous to each incubation period. Due to the high turnover rates of the benthic microflora, meteorological tides which occurred further, temporally, from the productivity measurements were deemphasized by using a weighted mean (the maximum of $6,12,18$, and 24 h means). An area near the muddy sand site was seined 3 times during the study to determine the species composition of the fishes frequenting that site. The presence of fish was used as a measure of the potential for biological disturbance.

For the taxonomic evaluation, live material was observed for about $45 \mathrm{~min}$ under a compound light microscope during each day of the study. Afterwards, diatom frustules were 'cleaned' by boiling samples in $20 \% \mathrm{HNO}_{3}$ and $\mathrm{K}_{2} \mathrm{Cr}_{2} \mathrm{O}_{7}$ to oxidize all organic matter. Following several rinses in distilled water, the resulting suspension was mounted in Hyrax for microscopic observation. The diatoms were identified and counted (300 cells slide ${ }^{-1}, 11$ slides) by Michael J. Sullivan (Department of Biological Sciences, Mississippi State 
University) using a Zeiss Standard Research 18 microscope employing phase optics.

Several in situ experiments were conducted to determine the relationship between light intensity and the photosynthetic rates of the benthic microflora. Gross primary productivity was measured using a Beckman 865 flow-through infrared carbon dioxide gas analyzer under different fractions of full sunlight. Each set of 20 cores ( 3 sets each for the sand and muddy sand sites) was incubated at 10 to 15 light levels: the different light levels were obtained by placing various layers of neutral density shade cloth over a frame covering the chambers. The sides and bottom of the light chambers were made opaque and the chambers were incubated normal to the sun to restrict the light regime to direct incoming quanta. Water temperature was maintained at $25 \pm 1^{\circ} \mathrm{C}$ by incubating the chambers in an ice bath near the sample sites or in the laboratory under $2000 \mathrm{~W}$ of white light. Productivity at each light level was expressed as a percent of the maximum gross productivity for that set. The photosynthesis vs light intensity curve was fit using the maximum entropy-moving average technique (Ulrych \& Bishop 1975, Ulrych \& Clayton 1976), as described in Shaffer \& Onuf (1985).

Statistical methods. The data were analyzed using pairwise time series, multichannel information, and $\mathrm{K}$ systems analyses (KSA), as detailed in Shaffer \& Cahoon (1987). In pairwise time series analysis, correlations are computed over all possible lags in the data. Consequently, this type of correlation can identify correspondences in variation that would not normally appear by computing an ordinary correlation coefficient. Multichannel information analysis, in addition to searching all possible lags, considers the interacting behavior of all variables simultaneously. Consequently, this technique can determine at what sampling frequency information peaks occur. Pairwise time series and multichannel information analyses rely on periodicities in a data set and are thus time dependent, whereas $\mathrm{K}$-systems analysis isolates important events in the data, periodic or aperiodic, and thus is event driven rather than time driven.

Mathematical and heuristic descriptions of how KSA operates have been detailed elsewhere (Jones 1985a, b, c, 1986, Shaffer \& Cahoon 1987). However, a simplified description of the important features of KSA will be given here to inform the reader without a detailed search through the literature. Essentially, KSA is a maximum entropy (opposed to a least squares) stepwise regression that uses events rather than variables as its fundamental unit. The main difference between KSA and standard statistical procedures is that the latter are designed to isolate overall or average effects. Consequently, standard statistical procedures are biased towards variables which contain broad effects and biased against variables whose effects are important, yet encompass a relatively narrow region of the data set (e.g. storm events). Contrarily, KSA examines the data over all possible regions and determines which minimal set of factors (variables acting alone or in combination) account for most of the behavior in the dependent variable. Consequently, KSA can pick out critical behaviors amongst variables which would normally go unnoticed. KSA has loose parallels with cluster analysis, principal components analysis (PCA), and regression. The first step in KSA is to classify the values of each independent variable into discrete intervals (e.g. temperature varying from 0 to $30^{\circ} \mathrm{C}$ is reduced to low [0 to 10], medium [11 to 20], and high [21 to 30]). Once the independent variables have been categorized, all possible variable combinations (i.e. factors) are produced. The effect of each factor on the dependent variable is computed and the factors (like the independent variables in multiple regression) are extracted to produce a minimal set which accurately describes the variation in the dependent variable. These factors operate on a $\mathrm{n} \times 2$ matrix which contains a static representation of the actual data of the dependent variable in one column and a dynamic reconstruction of that data in the other column. The reconstruction column iteratively checks the information content of all possible reconstructions of the dependent variable. Initially, the reconstruction column contains no information (the mean value of the dependent variable replicated $n$ times). As each factor enters the reconstruction the values in the reconstruction column more closely approximate the actual data. At each step the importance of each factor is computed with a distance measure (based on Shannon's measure of information) which determines the gain in system accuracy (in terms of explained variation) of the present over the previous reconstruction. The broadness of a factors effect is called region size and is computed as the ratio of the values in the reconstruction set affected by the factor to the total number of values in that set. Generally, the greater the number of variables represented in a factor, the narrower the region size (e.g. it is more likely for a factor containing only high light to occur than a factor containing high light, high tide, and high waves). Software for applying the algorithms used in K-systems analysis (Jones 1984, 1985a, b, c) should be available by late 1988 (marketer as yet unknown; contact author for details).

\section{RESULTS}

Photosynthetic rate increased as light intensity increased at low light intensities and was maximal over a wide range at high light intensities (Fig. 2). The saturating light level was determined to be $460 \mu \mathrm{E}$ 


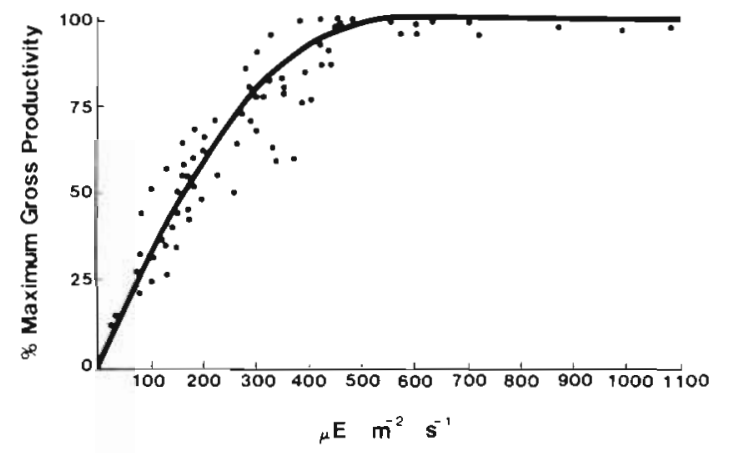

Fig. 2. Percent maximum gross productivity vs photon flux density under subaerial conditions with unaltered benthic microfloral communities from the sand and muddy sand sites

$\mathrm{m}^{-2} \mathrm{~s}^{-1}$ by averaging the points around the asymptote (Platt et al. 1975, Jassby \& Platt 1976, Harding et al. 1980). Correcting productivity by removing the variation in productivity due to sporadic changes in light (Shaffer \& Cahoon 1987) did not result in large deviations from uncorrected productivity, because light intensities during the incubation periods often approximated saturating conditions $\left(\bar{x}=469 \mu \mathrm{E} \mathrm{m}^{-2} \mathrm{~s}^{-1} \pm\right.$ 29.3 SE).

Both sample sites experienced highly variable day to day fluctuations in production which ranged from about $1.0 \mathrm{~g} \mathrm{C} \mathrm{m}^{-2} \mathrm{~d}^{-1}$ to unmeasurably slow rates, back to $1.0 \mathrm{~g} \mathrm{C} \mathrm{m}^{-2} \mathrm{~d}^{-1}$, within a $2 \mathrm{wk}$ period (Fig. 3). For the sand site, daily production averaged $466 \mathrm{mg} \mathrm{C} \mathrm{m}^{-2}$, and ranged from 0 to $1361 \mathrm{mg} \mathrm{C} \mathrm{m}{ }^{-2}$. For the muddy sand site, daily production averaged $900 \mathrm{mg} \mathrm{C} \mathrm{m}^{-2}$, and ranged from 0 to $1554 \mathrm{mg} \mathrm{C} \mathrm{m}^{-2}$ (Fig. 3). The monthly total at the sand site $\left(14.4 \mathrm{~g} \mathrm{C} \mathrm{m}^{-2}\right)$ was $48 \%$ of that for the muddy sand site $\left(27.9 \mathrm{~g} \mathrm{C} \mathrm{m}^{-2}\right)$. However, the highest hourly rates occurred at the sand site, but only for short periods ( 2 to $3 \mathrm{~h}$ on $11 \mathrm{~d}$ ) during late afternoon when the site became exposed subaerially These periods were accompanied by a dramatic increase in productivity, accounting for $43 \%$ of total monthly production for that site (Fig. 3). This increase was attributable to the mass upward migration of the diatom Hantzschia virgata (var. wittii [Grun.] Grun.) which is very common and abundant in marine intertidal areas (Michael J. Sullivan pers. comm.). An attempt was made to determine the depth this diatom occupied in the sediments during the morning, by extracting chlorophyll a from $2 \mathrm{~mm}$ sections of ten $2 \mathrm{~cm}$ deep cores: the chlorophyll a concentration was uniform to $0.6 \mathrm{~cm}$, slightly decreasing to $1 \mathrm{~cm}$, and sharply decreasing thereafter. This suggests that $H$. virgata was not concentrated at a particular depth during the morning sampling period. The presence of active chlorophyll a below $0.5 \mathrm{~cm}$ also suggests that the productivity measurements more closely approximated the actively photosynthesizing microfloral population

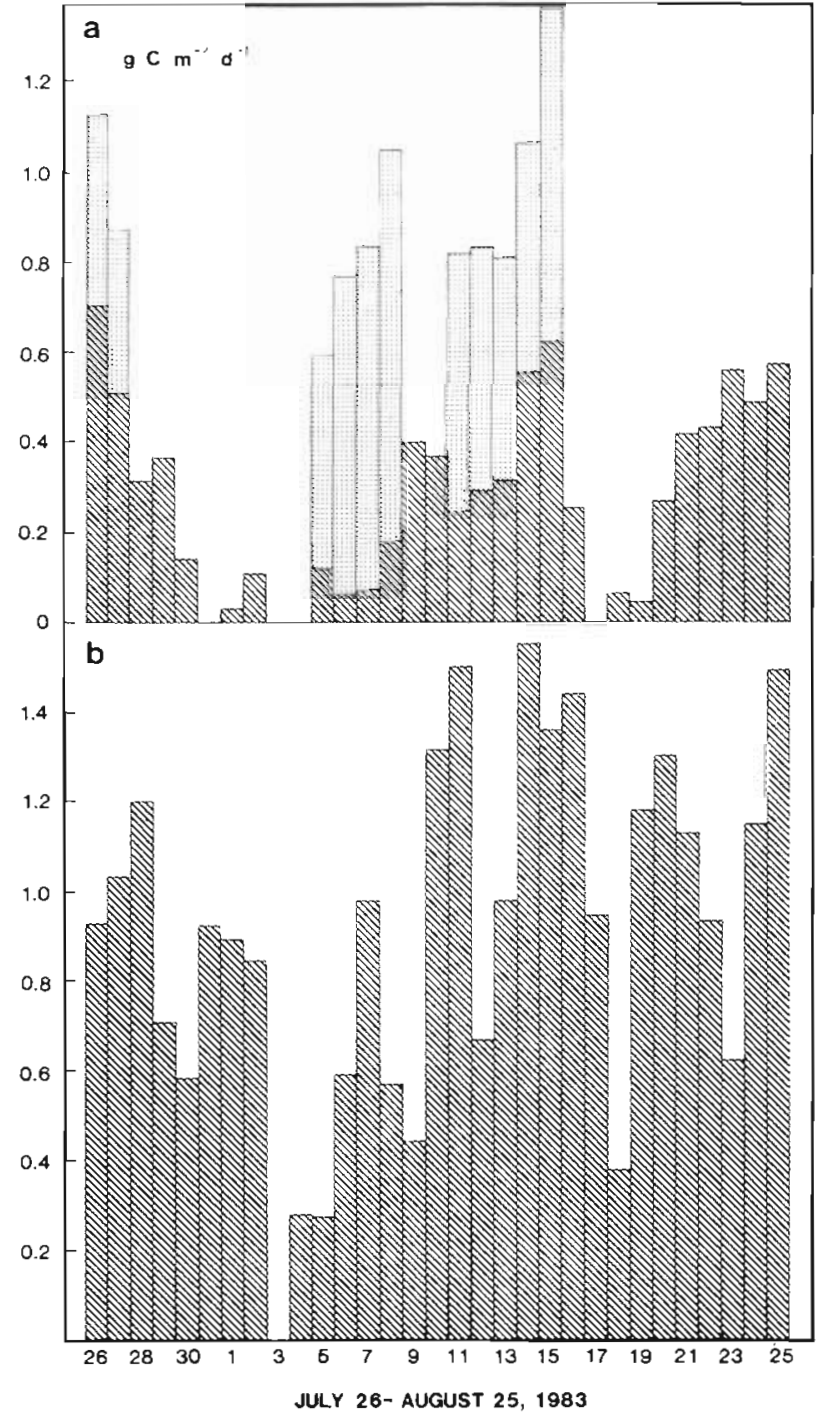

Fig. 3. Estimated daily gross primary production $\left(\mathrm{g} \mathrm{C} \mathrm{m}^{-2}\right)$ at (a) sand and (b) muddy sand sites. Diagonal shading: measurements made around noontime; stippling: measurements made during late afternoon when the sand site was exposed subaerially

(Taylor 1964, Fenchel \& Staarup 1971) than the total viable population.

Daily observation of live material revealed that the vast majority of the microflora at the sand site were comprised of diatoms. The microflora at the muddy sand site were primarily comprised of diatoms and secondarily (up to $30 \%$ ) by the blue-green algae Oscillatoria sp. and Merismopedia sp. A total of 44 diatom taxa were encountered at the 2 sites combined (Table 1). Under submerged conditions the sand site was dominated by Nitzschia cf. bacillariaeformis (Hust.), Amphora turgida (Greg.), Hantzschia virgata, and Navicula cancellata f. minuta (Grun.). During subaerial exposure (Table 1), $N$. bacillariaeformis and $A$. turgida became relatively less abundant due to the 
Table 1. Relative abundance (expressed as percent of total) of benthic diatoms from samples taken in Barataria Estuary, Louisiana, at the muddy sand site (MS), the sand site under submerged conditions (SS), and the sand site under subaerial exposure (SE). Dashes: taxon not collected

\begin{tabular}{|c|c|c|c|}
\hline Taxon & $\%$ SS & $\% \mathrm{SE}$ & $\% \mathrm{MS}$ \\
\hline Achnanthes curvirostrum Brun & 0.2 & - & 1.9 \\
\hline A. delicatula (Kütz.) Grun. & - & - & 0.7 \\
\hline A. punctifera Hust. & - & - & 0.3 \\
\hline Actinoptychus senarius Ehr. & 0.1 & - & - \\
\hline Amphiprora paludosa W Sm. & - & - & 0.6 \\
\hline Amphora caroliniana Giffen & 1.0 & - & 6.7 \\
\hline A. exigua Greg. & 0.7 & - & - \\
\hline A. proteus Greg. & 0.9 & - & 3.6 \\
\hline A. richardiana Choln. & 0.1 & - & 0.2 \\
\hline A. sabyii Salah & 0.1 & - & - \\
\hline A. turgida Greg. & 19.2 & 2.7 & 11.7 \\
\hline Cocconeis disculoides Hust. & 0.3 & - & - \\
\hline Cyclotella atomus Hust. & 0.2 & - & - \\
\hline C. caspia Grun. & 0.4 & - & 0.3 \\
\hline C. stylorum Brightwell & 0.7 & - & 0.3 \\
\hline Diploneis bombus Ehr. & 0.1 & - & 0.1 \\
\hline D. littoralis (Donk.) Cl. & 0.2 & - & 0.2 \\
\hline Eunotogramma laeve Grun. & 0.8 & - & 0.4 \\
\hline $\begin{array}{l}\text { Hantzschia virgata var. witti } \\
\text { (Grun.) Grun. }\end{array}$ & 11.5 & 74.7 & 1.8 \\
\hline Navicula abunda Hust. & 2.3 & - & 2.0 \\
\hline N. ammophila Grun. & 1.6 & 1.0 & 1.9 \\
\hline N. cancellata f. minuta Grun. & 11.4 & - & 0.7 \\
\hline N. consentanea Hust. & 0.3 & - & 14.1 \\
\hline N. cruciculoides Brockmann & 1.0 & - & 6.3 \\
\hline N. forcipata Grev. & 0.2 & - & 0.2 \\
\hline N. gregaria Donk. & 0.2 & - & 1.4 \\
\hline N. hudsonis Grun. & - & - & 0.1 \\
\hline N. salinarum Crun. & 1.8 & - & 14.1 \\
\hline N. salinicola Hust. & - & - & 0.1 \\
\hline N. subapiculata (Grun.) Hust. & 5.4 & - & 19.1 \\
\hline N. subinflatoides Hust. & 0.1 & - & 0.7 \\
\hline N. taraxa Hohn \& Hellerm. & - & - & 0.1 \\
\hline$N$ tenera Hust. & 0.1 & - & - \\
\hline Navicula sp. $\# 1$ & 4.7 & - & 2.0 \\
\hline Navicula sp. \#2 & 0.1 & - & - \\
\hline Nitzschia cf bacillariaeformis Hust. & 31.9 & 16.3 & 0.9 \\
\hline N. fontifuga Choln. & 0.1 & - & 3.3 \\
\hline N. panduriformis var. continua Grun. & 0.2 & - & - \\
\hline N. quadrangula (Kütz.) Lange-B. & 0.2 & 0.3 & 0.1 \\
\hline Plagiogramma tenuissimum Hust. & 0.1 & - & - \\
\hline Stauroneis salina W. Sm. & 0.2 & - & 1.8 \\
\hline $\begin{array}{l}\text { Thalassiosira decipiens (Grun.) } \\
\text { Jørgensen }\end{array}$ & 2.1 & - & 1.1 \\
\hline T. eccentrica (Ehr) $\mathrm{Cl}$. & 0.1 & - & - \\
\hline Tropidoneis semistriata (Grun.) $\mathrm{Cl}$. & - & 5.0 & 1.1 \\
\hline Total no of taxa & 37 & 6 & 34 \\
\hline
\end{tabular}

massive upward migration of $H$. virgata, and to a lesser degree Tropidoneis semistriata (Grun.). The muddy sand site was dominated by Navicula subapiculata [(Grun.) Hust.], Navicula salinarum (Grun.), Navicula consentanea (Hust.), and $A$. turgida (Table 1).

The responses over time of 11 independent variables and productivity are shown in Fig. 4. For the sand site the highest overall correlations between productivity and the individual variables occurred for benthic community respiration $(r=0.92)$, chlorophyll a $(r=0.88)$, and meteorological tides $(r=-0.84)$. For the muddy sand site, variables most highly correlated were the same (chlorophyll a $[\mathrm{r}=0.75\}$, benthic community respiration $[\mathrm{r}=0.72]$, and meteorological tides $[\mathrm{r}=$ $0.46]$ ), but the correlations were lower. The pairwise time series of productivity and the independent variables revealed that coherency and phase lag (Shaffer \& Cahoon 1987) varied greatly through time, and common peaks among variables were not clear. The multichannel information analysis confirmed this for the muddy sand site: the collective responses of all the measured variables produced only weak peaks (Fig. 5) at slightly under $3 \mathrm{~d}\left(0.34\right.$ cycles $\left.\mathrm{d}^{-1}\right)$ and $10 \mathrm{~d}$ $\left(0.11\right.$ cycles $\left.\mathrm{d}^{-1}\right)$, with the maximum occurring at $30 \mathrm{~d}$ $\left(0.03\right.$ cycles $\left.d^{-1}\right)$. Contrarily, for the sand site, distinct peaks occurred at slightly less than $3 \mathrm{~d}$ ( 0.34 cycles $\left.\mathrm{d}^{-1}\right)$, and $7 \mathrm{~d}\left(0.15\right.$ cycles $\left.\mathrm{d}^{-1}\right)$, again with the greatest peak at $30 \mathrm{~d}$.

K-systems analysis (Table 2) isolated the events which accounted for most of the behavior in productivity. For both sites 2 levels (high values, low values) per variable sufficed, with the exception of meteorological tides which required 3 levels to separate set-ups (positive values caused by southerly winds) and set-downs (negative values caused by northerly winds) from calm conditions (zero value, when the tidal height was dominated by the astronomic component). For the sand site, the greatest decreases (Factors 1, 5) in productivity were accompanied by low chlorophyll a concentrations, low respiration, high wave heights, high tide heights and high meteorological tides. The greatest increases (Factors 2,4) were accompanied by the opposite, with low light levels reducing the increase by greater than $50 \%$ (compare Factor 2 with Factor 4). For the muddy sand site, large decreases (Factors 1, 5, 6) also occurred during high meteorological tides, accompanied by low chlorophyll a, respiration, and light intensities, with the greatest decreases (Factor 5) coinciding with high biological activity. The fauna primarily responsible for the activity were: darter goby Gobionellus boleosoma, salt marsh killifish Fundulus heteroclitus, diamond killifish Adinia xenica, striped mullet Mugil cepalis, sheepshead minnow Cyprinodon variegatus, gulf menhaden Brevoortia patronsus, spot Leiostomus axanthurus, and bay anchovy Anchoa mitchillidiaphena. The greatest increases (Factors 2, 4) were accompanied by high chlorophyll a concentrations, high light intensities, low tides and low biological activity, over the full range of meteorological tides. The KSA model for the sand site reconstructed $98 \%$ of the total information, while only $77 \%$ of the total information was reconstructed for the muddy sand site. 
Fig. 4. Temporal variation of several variables at (left) sand and (right) muddy sand sites. (a) Uncorrected (-) and corrected (--) benthic microfloral productivity (BMP). (b) Wave height (Waves, sand), and biological activity (Bio, muddy sand). (c) Chlorophyll a (Chl a). (d) Productivity of the water column (WCP). (e) Light intensity (Light). (f) Water temperature (Temp). (g) Benthic community respiration (Resp). (h) Tidal height (TH) (-), and meteorological tides (Meteor) (--). (i) Salinity (both sites, with upper $\mathrm{I}$ for sand and lower $r$ for muddy sand) and mean tidal range (TR, both sites). (j) Initial dissolved oxygen concentration (IDO). For ease in visualizing relations, data points were connected using a non-linear fit (SAS Institute 1985). Also shown is pairwise correlation ( $r$ ) of the variables with benthic productivity

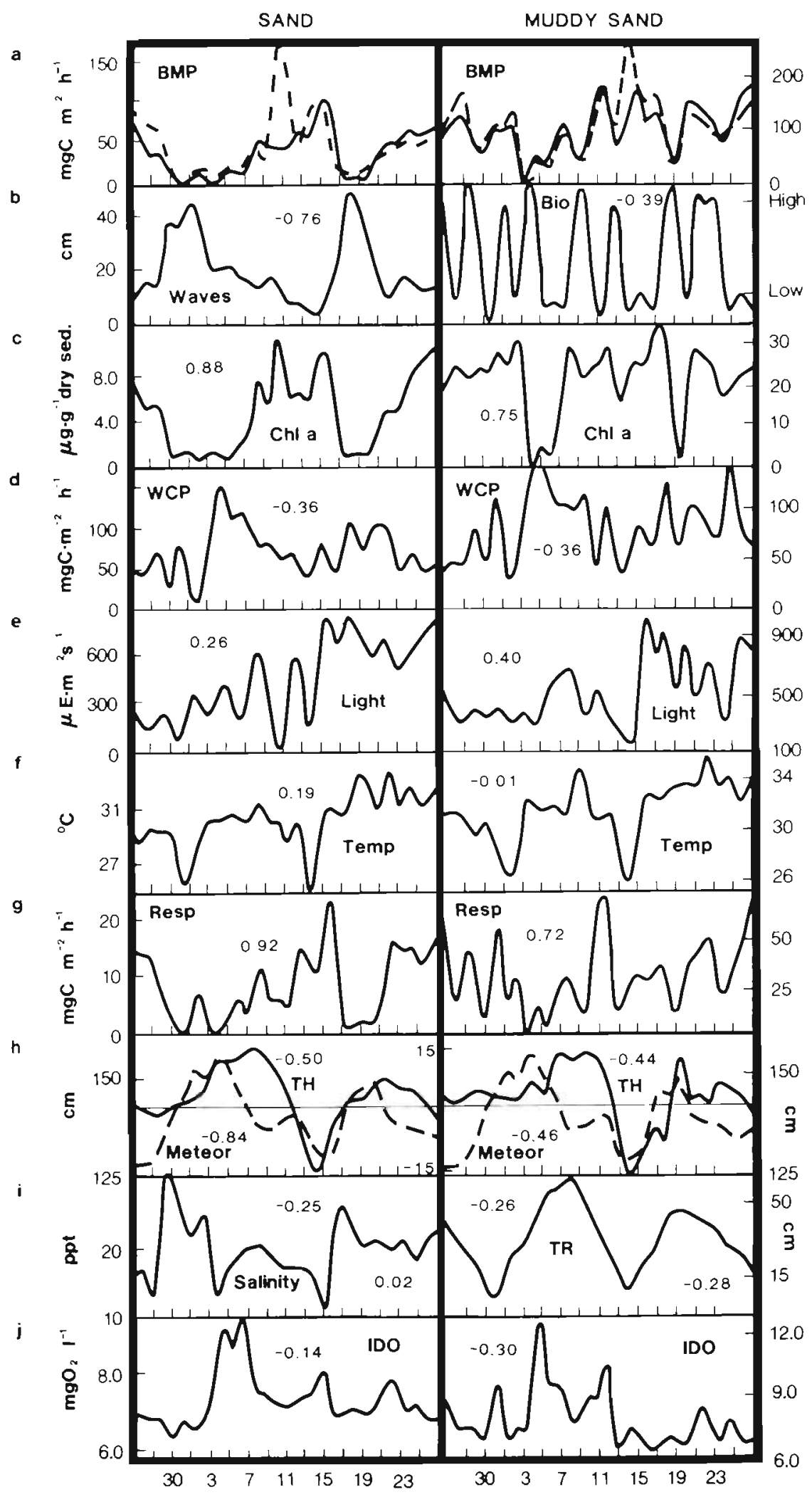

JULY 26-AUGUST 25,1983 


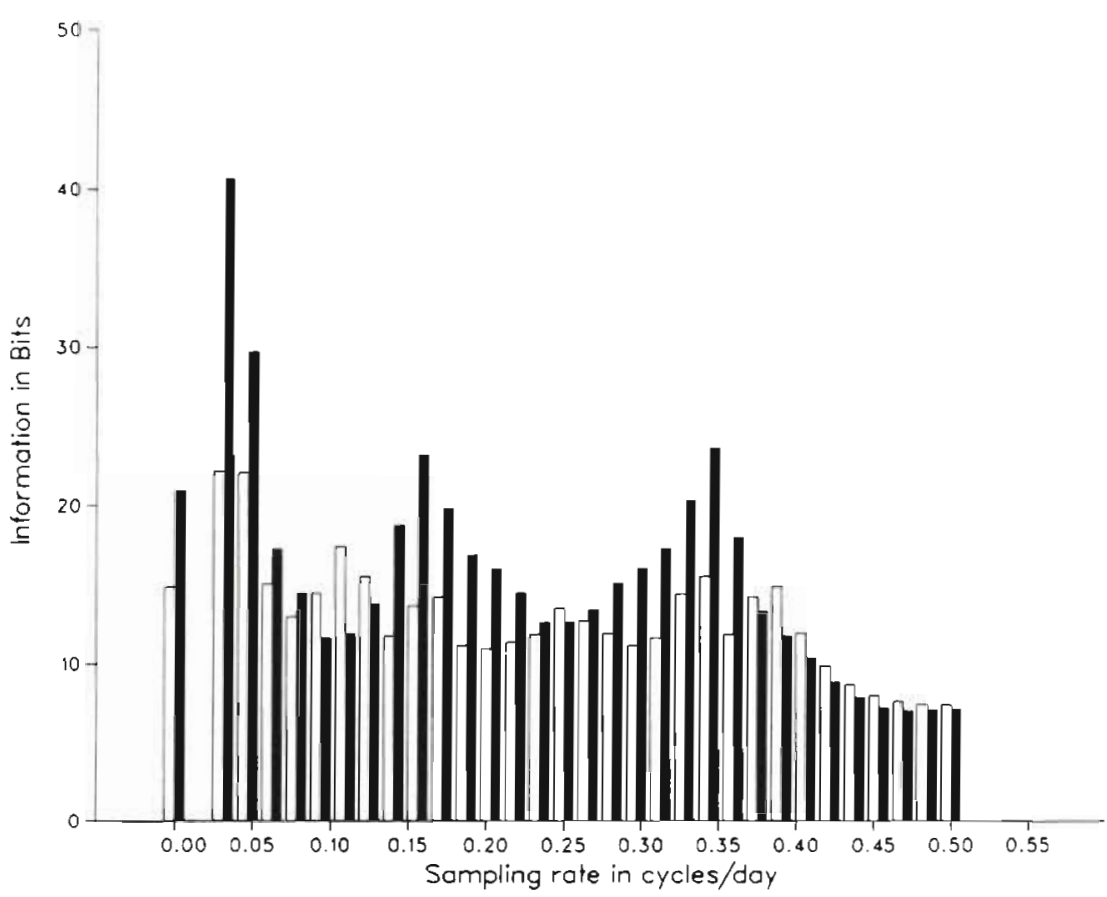

Fig. 5. Total information for all variables combined at different frequencies. Black bars: sand response; oper bars: muddy sand response

\section{DISCUSSION}

The saturating light level, determined to be $460 \mu \mathrm{E}$ $\mathrm{m}^{-2} \mathrm{~s}^{-1}$, was almost 3 times lower than the saturating light level for Mugu Lagoon, California, but more than twice as high as that measured for most other regions (Taylor 1964, Cadée \& Hegeman 1974, Colijn \& van Buurt 1975, Admiraal 1977). It must be noted that productivity was measured during the month-long study with the sediment cores submersed in water, while the photosynthesis vs light intensity relation was measured with the cores exposed to air so that samples could be subjected to many different light levels over relatively short periods of time. Leach (1970) found benthic microfloral productivity was similar under exposed and submerged conditions. More recently, Holmes \& Mahall (1982) observed that subaerial exposure caused an initial increase in productivity, followed by a decrease caused by desiccation. Preliminary work (Douglas Cushman, Louisiana State University, unpubl.) using samples from the study sites in Fig. 1 supports the results of Holmes \& Mahall, indicating that maximum productivity is achieved after sediments become subaerially exposed, yet remain moist $(\sim 97 \%$ relative humidity inside incubation chambers). For the photosynthesis vs light study the cores were kept moist and thus subaqueous productivity may have been overestimated. However, this overestimate is not expected to affect the relation of photosynthesis vs light intensity because measurements are expressed in terms of percent maximum productivity.

As might be expected, the productivity of the benthic microflora varied greatly during the month, ranging from unmeasurably slow rates to rates exceeding $1.5 \mathrm{~g}$ C $\mathrm{m}^{-2} \mathrm{~d}^{-1}$. Surprisingly, dramatic variability also occurred within individual days at the sand site (with morning rates of less than $20 \mathrm{mg} \mathrm{C} \mathrm{m}^{-2} \mathrm{~h}^{-1}$ followed by afternoon rates of greater than $200 \mathrm{mg} \mathrm{C} \mathrm{m}^{-2} \mathrm{~h}^{-1}$ ). At the sand site failure to account for productivity during late afternoon would have resulted in an underestimate of monthly production by almost $50 \%$, and would have produced maximum productivity less than $100 \mathrm{mg} \mathrm{C}$ $\mathrm{m}^{-2} \mathrm{~h}^{-1}$. Contrarily, hourly rates at the muddy sand site regularly exceeded $150 \mathrm{mg} \mathrm{C} \mathrm{m}^{-2} \mathrm{~h}^{-1}$. Consequently, even if productivity were measured everyday at around noontime, monthly production at the muddy sand site would have been estimated to be about 4 times greater than monthly production at the sand site. In actuality, productivity at the sand site may approach that at the muddy sand site: besides the tremendous productivities measured during certain afternoons, up to $90 \%$ of the water column productivity at the sand site is directly attributable to the benthic microflora (Shaffer \& Sullivan 1988). Physical disturbance displaces the microflora almost constantly in this unprotected regime. Complete refuge occurs only during periods of subaerial exposure when the (presumably) steady upward migration of benthic diatoms results in accumulation on the sediment surface. Under calm conditions and low wave heights, the accumulation of diatoms on the sediment surface was clearly visible. I observed, on several occasions during the course of the study, the removal of this entire surface film as a result of an isolated wave created by the wake of a power boat. 


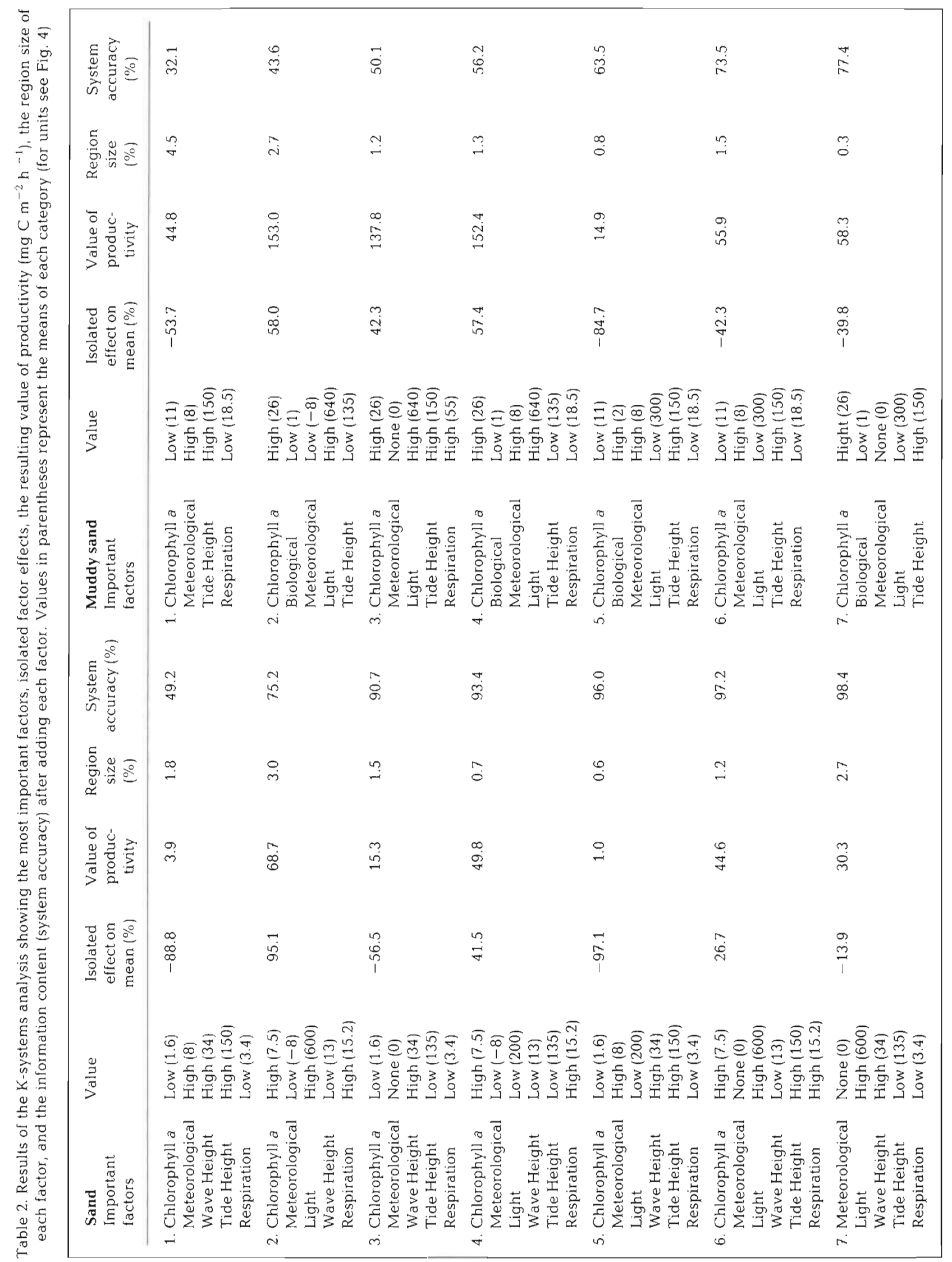


Cyclic patterns of productivity were evident at the sand site (Figs 4 and 5), but were distorted by episodic meteorological events. The information peaks at nearly $1 / 2 \mathrm{wk}$ and $1 \mathrm{wk}$ periods suggest the importance of an astronomic tidal component. Two large meteorological tides (see wave height and meteorological tides during $30 \mathrm{Jul}$ to $3 \mathrm{Aug}$ and 17 to $20 \mathrm{Aug}$ in Fig. 4b, h) were sufficient to mask the 14 d lunar component, which was maximal around $26 \mathrm{Jul}, 9 \mathrm{Aug}$, and 23 Aug (i.e. the largest differences between the actual tide height and the meteorological tide height in Fig. 4h). The combination of these 2 components accounts for the $30 \mathrm{~d}$ spike (Fig. 5). This spike must be interpreted cautiously because of the lack of longer term data, but does suggest that the full range of variability was not resolvable over the sampling period of $1 \mathrm{mo}$.

The information structure for the muddy sand site displayed only weak peaks. Presumably, this occurred because of the high frequency cycling of biological activity which was prominent at around $3 \mathrm{~d}$ periods (Fig. 4b, muddy sand). Indeed the multichannel information analysis (Fig. 5) reveals weak high frequency peaks of information at about $2 \frac{1 / 2}{2}$ and $3 \mathrm{~d}(0.38$ and 0.34 cycles $\mathrm{d}^{-1}$ ) periods. The next peak occurs at $10 \mathrm{~d}$ periods, presumably attributable to a combination of physical and biological processes.

$\mathrm{K}$-systems analysis (Table 2) resolved both general and specific patterns in the data. Generally, decreases at both sites were accompanied by low chlorophyll a concentrations, low respiration, and low light intensities. Light appears to be more closely coupled with productivity at the muddy sand site than at the sand site: under low light intensities, but otherwise ideal conditions (calm, with high chlorophyll a and low biological disturbance [Factor 7]), productivity decreases. Contrarily, at the sand site, productivity continues to increase under low light intensities, but otherwise ideal conditions (high chlorophyll a, set-down, and low wave height [Factor 4]).

The 2 sites differed mainly in the types and degrees of disturbances. For the sand site, wave processes were primarily responsible for disrupting the benthos. These waves were primarily wind driven during conditions of set-up (Factors 1 and 5), and were primarily produced by the wakes of power boats during calm conditions (Factors 3 and 7). The ridge and runnel system mitjgated these disturbances at the beginning, middle, and end of the study. A subaqueous parallel sand ridge existed approximately $20 \mathrm{~m}$ seaward of the sample site on $26 \mathrm{Jul}$, and slowly migrated shoreward until the high wave activity beginning $30 \mathrm{Jul}$. These waves greatly accelerated the migration, welding the ridge to the sandspit within $2 \mathrm{~d}$. Prior to $30 \mathrm{Jul}$, the ridge caused power boat waves to break before reaching the sample site, greatly reducing their impact on the benthos. A new ridge began to form midway through the study, but was destroyed by a second large storm event beginning 17 Aug. After that event a new ridge did not reform until the last week of the study. Factors 1 and 5 (Table 2) correspond to the periods where no subaqueous sand bar was present, while Factor 7 corresponds to calm periods when waves created by power boats broke once before reaching the sample site, and thus did not decrease productivity as severely as similar conditions (Factor 3) when the sand bar was absent. Meteorological tides were not as important at the muddy sand site, as is indicated by increases in productivity during all 3 meteorological conditions (Factors 2, 3 , and 4 for the muddy sand site). However, the largest decreases in productivity at the muddy sand site (Factors 1,5 , and 6) occurred only during set-up conditions. During 2 of these periods, high waves coincided with very high tides (Fig. 4b, h) resulting in wave uprush which overtopped the sandspit, blanketing the muddy sand site with 5 to $6 \mathrm{~cm}$ of fresh sand. These periods coincided with marked decreases in benthic microfloral standing crop (Fig. 4c, muddy sand). The benthic microfloral standing crop rebounded very quickly to the disturbances, within $24 \mathrm{~h}$ (see 18 and 19 Aug, Fig. 4c) on the second occasion. Scouring removed the top 2 to $3 \mathrm{~mm}$ oxidized layer of the sediments as was indicated by the interface of fresh sands and black (reduced) muddy sands. An important stock of motile diatoms in these sediments migrated through the 5 to $6 \mathrm{~cm}$ thick sands within $24 \mathrm{~h}$. These diatoms found below the photic zone (Steele \& Baird 1968, Hunding 1971, Cadée \& Hegeman 1974, Joint 1981, Joint et al. 1982, Grant et al. 1986, Lukatelich \& McComb 1986) may constitute an important evolutionary mechanism enabling rapid response to large disturbances. Presumably, this mechanism accounts for the apparent vertically homogeneous distribution of Hantzschia virgata, the dominant diatom found at the sand site.

For the muddy sand site, a second type of disturbance caused by biological activity occurred with a more frequent periodicity (Fig. 4b). Biological disturbance of the benthic microflora occurred via 3 mechanisms: feeding of fishes directly on the microflora (e.g. darter goby [Fitzhugh \& Fleeger 1985], striped mullet [Moriarty 1976]), feeding of fishes on benthic meiofauna which displaces the microflora from the benthos into the water column (e.g. several gobies [Pezold 1979, Darcy 1980, Hicks \& Coull 1983, Fitzhugh \& Fleeger 1985], killifish and spot (Darnell 1958]), and inadvertent physical disturbance caused by large schools of fish swimming in the shallow waters overlaying these sediments (e.g. gulf menhaden and bay anchovy (Darnell 1958]).

Biological disturbance by fish activity was not apparent at the sand site: the benthic community was 
primarily autotrophic, as was revealed by the tight coupling of chlorophyll a and respiration in the $\mathrm{K}$ systems analysis and the nearly perfect correlation between respiration and productivity ( $\mathrm{r}=0.92)$. Juvenile fishes, which dominated the seine samples, show preference to the more secluded areas of Gulf coast estuaries (Deegan 1985).

In summary, large fluctuations in productivity occurred several times at both sites during the month. In addition, productivity at the sand site showed dramatic intra-diel increases. The benthos in this area variably augments water column productivity, depending on the degree of physical disturbance (Shaffer \& Sullivan 1988). Failure to observe the relationship between physical processes and benthic microfloral productivity would result in a tremendous error in assessing the importance of the beachface habitat, producing claims that the more protected areas are perhaps 4 times more productive, when in actuality the productivity may be similar. The implications of this study, as to the intensity of sampling required to obtain a reliable estimate of annual production of the benthic microflora, are not as gloomy as they may appear. K-systems analysis indicated that easily monitored physical variables (e.g. tide and wave height, meteorological events, light intensity) measured in combination, may produce realistic estimates of difficult-to-measure ecosystem functions such as primary productivity (Shaffer 1988 [companion article]). More detailed studies are required before this technique could become tractable: first, a laboratory experiment producing data on all possible 2-level combinations of the variables should be conducted. Third and fourth levels could be added later to resolve 'outlier' (e.g. hurricane) conditions and to fine tune the model. Second, seasonal studies (fall, winter, spring) similar to that of this report are required to determine whether the relationships discussed above are applicable year round and to calibrate the laboratory model. A rule-base could then be established from the response of productivity to all events and interrelationships among events (Shaffer 1988). The resultant information could be used to generate a dynamic eventdriven expert systems model. This type of model could also incorporate processes which occur over different time scales (e.g. physical turnover of a ridge and runnel system and biological turnover of a benthic microfloral system) by simple memory updates (Coulson et al. 1987).

Acknowledgements. This research was sponsored by Louisiana State University's Alumni Federation Fellowship and Department of Marine Sciences. I am indebted to Harry Schafer for permission to use the Grand Terre Facility and to Vince Guillory and Mark Chatry for their assistance during the study. I thank James Gosselink, Larry Rouse, James Geaghan, James Grace, Irv Mendelssohn, Bush Jones and 3 anonymous reviewers for their helpful comments on earlier versions of the manuscript and Mike Sullivan for his invaluable taxonomic assistance and his valued contribution of Table 1

\section{LITERATURE CITED}

Adams. R. D., Barrett, B. B., Blackmon, J. H., Gane, B. W., McIntyre, W. G. (1976). Barataria Basin: geologic processes and frame-work. Center for Wetland Resources, Louisiana State University, Baton Rouge, Sea Grant Publ. No. LSU-T-76-006

Admiraal, W. (1977). Influence of light and temperature on the growth rate estuarine benthic diatoms in culture. Mar. Biol. 39: 1-9

Baillie, P. W., Welsh, B. L. (1980). The effect of tidal resuspension on the distribution of intertidal epipelic algae in an estuary. Estuar coast. mar. Sci. 10: 165-180

Byrne, P., Borengasser, M., Drew, G., Muller, R. A., Smith, B. L., Wax, C. (1976). Barataria Basin: hydraulic and climatologic processes. Louisiana State Univ., Sea Grant Publ. No. LSU-T-76-010

Cadée, G. C., Hegeman, J. (1974). Primary production of the benthic microflora living on tidal flats in the Dutch Wadden Sea. Neth. J. Sea Res. 8: 260-291

Cadée, G. C., Hegeman, J. (1977). Distribution of primary production of the benthic microflora and accumulation of organic matter on a tidal flat area, Balgzand, Dutch Wadden Sea. Neth. J. Sea Res. 11: 24-41

Colijn, F., van Buurte, G. (1975). Influence of light and temperature on the photosynthetic rate of marine benthic diatoms. Mar Biol. 31: 209-214

Colijn, F., Jonge, $V \mathrm{~N}$. de (1984). Primary production of microphytobenthos in the Ems-Dollard estuary. Mar. Ecol. Prog. Ser. 14: 185-196

Coulson, R. N., Folse, J., Loh, D. K. (1987). Artificial intelligence and natural resource management. Science 237: 262-267

Darcy, G. H. (1980). Comparison of ecological and life history information on gobiid fishes, with emphasis on the Southeastern United States. NOAA Technical Memorandum NMFS-SEFC-15

Darnell, R. M. (1958). Food habits of fishes and larger invertebrates of Lake Pontchartrain, Louisiana, an estuarine community. Publs. Inst. mar Sci. Univ. Texas 5: 353-416

Deegan, I. A. (1985). The population ecology and nutrient transport of gulf menhaden in Fourleague Bay, Louisiana. Ph.D. thesis, Louisiana State University, Baton Rouge

Es, F. B. van (1982). Community metabolism of intertidal flats in the Ems-Dollard estuary. Mar. Biol. 66: 95-108

Fenchel, T., Staarup, B. J. (1971). Vertical distribution of photosynthetical pigments and the penetration of light in marine sediments. Oikos 22: 172-182

Fitzhugh, G. R., Fleeger, J. W. (1985). Goby (Pisces: Gobiidae) interactions with meiofauna and small macrofauna. Bull. mar. Sci. 36: 436-444

Folk, R. L. (1968). Petrology of sedimentary rocks. Hemphills, Austin

Gallagher, J. T., Daiber, F. C. (1974). Primary productivity of edaphic algal communities in a Delaware salt marsh. Limnol. Oceanogr. 19: 390-395

Grant, J., Bathmann, U. V., Mills, E. L. (1986). The interaction between benthic diatom films and sediment transport. Estuar coast. Shelf Sci. 23: 225-238 
Harding, L. W., Jr, Meeson, B. W., Prézlin, B. B, Sweeney, B. M. (1980). Diel periodicity of photosynthesis in marine phytoplankton. Mar. Biol. 61: 95-105

Hicks, G. R. F., Coull, B. C. (1983). The ecology of marine meiobenthic harpacticoid copepods. Oceanogr. mar. Biol. A. Rev. 21: 67-175

Holmes, R. W., Mahall, B. E. (1982). Preliminary observations on the effects of flooding and desiccation upon the net photosynthetic rates of high intertidal sediments. Limnol. Oceanogr. $27 \cdot 954-958$

Hunding, C. (1971). Production of benthic microalgae in the littoral zone of a eutrophic lake. Oikos 22: 389-397

Jassby, A. D., Platt, T (1976). Mathematical formulation of the relationship between photosynthesis and light for phytoplankton. Limnol. Oceanogr. 21. 540-547

Joint, I. R. (1981). Growth and survival of estuarine microalgae. In: Jones, N. V., Wolff, W. J. (eds.) Feeding and survival strategies of estuarine organisms. Plenum Press, New York, p. 17-28

Joint, I. R. (1978). Microbial production of an estuarine mudflat. Estuar. coast. mar. Sci. 7: 185-195

Joint, I. R., Gee, J. M., Warwick, R. M. (1982). Determination of fine-scale vertical distribution of microbes and meiofauna in an intertidal sediment. Mar Biol. 72: $157-164$

Jones, B. (1984). Determination of unbiased reconstructions. Int. J. gen. Syst. 10: 169-176

Jones, B. (1985a). A greedy algorithm for a generalization of the reconstruction problem. Int. J. gen. Syst. 11: 63-68

Jones, B. (1985b). Reconstructability analysis of general functions. Int. J. gen. Syst. 11: 133-142

Jones, B. (1985c). Reconstructability considerations with arbitrary data. Int. J. gen. Syst. 11. 143-151

Jones, B. (1986). K-systems analysis versus classical multivariate analysis. Int. J. gen. Syst. 12: 1-6

Krumbein. W. C., Aberdeen, E. (1937). The sediments of Barataria Bay. J. Sedim. Petrol. 7: 3-17

Leach, J. H. (1970). Epibenthic algal production in an intertidal mudflat. Limnol. Oceanogr. 15: 514-521

Lorenzen, C. (1967). Determination of chlorophyll and pheopigments: spectrophotometric equations. Limnol. Oceanogr 12: $343-346$

Lukatelich, R. J., McComb, A. J. (1986). Distribution and abundance of benthic microalgae in a shallow southwestern Australian estuarine system. Mar. Ecol. Prog. Ser. 27 : $287-297$

Moriarty, D. J. W. (1976). Quantitative studies on bacteria and algae in the food of the mullet Mugil cephalus $\mathrm{L}$. and the prawn Metapenneus bennettae (Racek and Dall). J. exp. mar. Biol. Ecol. 22: 131-143

Pamatmat, M. M. (1968). Ecology and metabolism of a benthic community on an intertidal sand flat. Int. Rev. ges. Hydrobiol. 53: 211-298

Pezold, F. L. (1979). The comparative ecology of the darter goby, Gobionellus boleosoma and the freshwater goby, Gobionellus shufeldtii (Pisces: Gobiidae) in the Mississippi River Delta Estuary. M.S. thesis, University of New Orleans
Platt, T., Denmon, K. L., Jassby, A. D. (1975). The mathematical representation and prediction of phytoplankton productivity. Fish. mar. Serv. Tech. Rep. 523: 1-110

Pomeroy, L. R. (1959). Algal productivity in salt marshes of Georgia. Limnol. Oceanogr. 4: 386-397

Reimann, B. (1978). Carotenoid interference in the spectrophotometric determination of chlorophyll degradation products from natural populations of phytoplankton. Limnol. Oceanogr. 23: 1059-1066

Rizzo, W. M., Wetzel, R. L. (1985). Intertidal and shoal benthic community metabolism in a temperate estuary: studies of spatial and temporal scales of variability. Estuaries 8: $342-351$

Rutgers van der Loeff, M. M., Es, F. B. van, Helder, W., de Vries, R. I P. (1981). Sediment water exchanges of nutrients and oxygen on tidal flats in the Ems-Dollard estuary. Neth. J. Sea Res. 15: 113-129

SAS Institute Inc. (1985). SAS/GRAPH User's Guide. 5th edn. Cary, North Carolina

Shaffer, G. P. (1988). A comparison of benthic microfloral production on the West and Gulf coasts of the United States: an introduction to the dynamic K-systems model. Mar. Ecol. Prog. Ser. 43: 55-62

Shaffer, G. P., Sullivan, M. J. (1988). Water column productivity attributable to displaced benthic diatoms in well-mixed shallow estuaries. J. Phycol. (in press)

Shaffer, G. P., Cahoon, P. (1987). Extracting information from ecological data containing high spatial and temporal variability: benthic microfloral production. Int. J. gen. Syst. 13: $107-123$

Shaffer, G. P., Onuf, C. P. (1985). Reducing the error in estimating annual production of benthic microflora: hourly to monthly rates, patchiness in space and time. Mar. Ecol. Prog. Ser. 26: 221-231

Shaffer, G. P., Onuf, C. P. (1983). An analysis of factors influencing the primary production of the benthic microflora in a southern California lagoon. Neth. J. Sea Res. 17: 126-144

Shamban, A. J. (1985). Historical evolution, morphology, and processes of Barataria Pass, Louisiana. M.S. thesis, Louisiana State University, Baton Rouge

Strickland, J. D., Parsons, T R. (1972). A practical handbook for seawater analysis. Bull. Fish. Res. Bd Can. 167: 1-311

Steele, J. H., Baird, I. E. (1968). Production ecology of a sandy beach. Limnol. Oceanogr 13: 14-25

Taylor, W R. (1964). Light and photosynthesis in intertidal benthic diatoms. Helgoländer wiss. Meeresunters. 10: $29-37$

Ulrych, T. J., Bishop, I N. (1975). Maximum entropy spectral analysis and autoregressive decomposition. Rev. Geophys 13: $183-200$

Uhych, T J., Clayton, R. W. (1975). Time series modelling and maximum entropy. Phys. Earth Planetary Inter. 12 $188-200$

Van Raalte, C. D., Valiela, I., Teal, J. M. (1976). Production of benthic salt marsh algae: light and nutrient limitation. Limnol. Oceanogr $21 \quad 862-872$

Zedler, J. B. (1980). Algal mat productivity: comparisons in a salt marsh. Estuaries 2: 122-131 